designed to characterize the enzyme and to identify the reducing material, and quantitative measures of the amount of cellulose hydrolysed, are proceeding.

This work forms part of an investigation on the physiology of Limnoria, supported by funds of Initiative 171 of the State of Washington.

D. L. RAY Jean R. Julian

Department of Zoology and the Oceanographic Laboratories,

University of Washington, Seattle 5, Washington. Aug. 9.

1 Yonge, C. M., Nature, 119, 855 (1927).

2 Hungate, R. F., Bact. Rev., 14, 1 (1950).

Stanier, R. Y., Bact. Rev., 6, No. 3, 143 (1942).

\section{Caffeine in Cacao Beans}

Ir is stated by Knapp ${ }^{1}$ in his standard text-book on "Cacao Fermentation" that caffeine, the minor alkaloid of cocoa, occurs in fresh cacao beans as an L-epicatechin-caffeine complex. This statement would appear to be based on the work of Ultée and Van Dorssen ${ }^{2}$, who isolated such a complex from aqueous extracts of beans, and on the mainly unpublished work of Adam ${ }^{3,4}$, who showed that simple mixing of aqueous solutions of the two substances produced the sparingly soluble complex.

However, by molecular weight determinations, Ultée and Van Dorssen ${ }^{2}$ showed that the complex was completely dissociated in aqueous solution. We attempted to find whether the caffeine was present in the fresh bean in a free or combined form by paper chromatography of various extracts with a variety of developers. In every case caffeine was found only in the free form on the paper. It was detected by its absorption of ultra-violet light ${ }^{5}$.

Synthetic preparations of the complex were made by simply mixing aqueous solutions of the two components. A precipitate was obtained over a wide range of concentrations and crystallized from methanol as short prisms of melting point $83^{\circ}$ (uncorr.). The anhydrous preparation was found by analysis to be a $1: 1$ addition compound of caffeine and L-epicatechin ${ }^{2,4}$. However, when such a preparation was chromatographed on a paper strip against an aqueous stationary phase, the two components were separated and had their usual $R_{F}$ values even in neutral solvents. They also separate on chromatography in water alone. Further, the caffeine could be completely extracted from an aqueous suspension of the material by cold chloroform.

A discussion of whether caffeine exists in the cacao bean free or as a dissociated complex would appear fruitless. The isolation of such an easily formed material as the L-epicatechin-caffeine complex is most certainly not proof that it exists as such in the bean.

W. G. C. Forsyth

Colonial Microbiological Research Institute, Trinidad,

British West Indies. July 25.

${ }^{1}$ Knapp, A. W., "Cacao Fermentation" (Bale, Sons and Curnow, Ltd., 1937).

2 Ult6é, A. J., and Van Dorssen, W., Cultuurgids, 2, 529 (1909).

s Adam, W. B., Analyst, 53, 369 (1928).

Adam, W. B. (private communication, 1951).

'Markham, R., and Smith, J. D., Biochem. J., 45, 294 (1949),

\section{Acid-soluble Lignin}

Is a communication 1 prepared and accepted for presentation at the Twelfth International Congress of Pure and Applied Chemistry (New York, Sept. 1951), it is shown that, in the course of the delignifica. tion of wood by sodium chlorite buffered at $p \mathrm{H} 6 \cdot 3$, there is formed and retained in the wood residue (holocellulose) a modification of lignin which is not determined as a solid residue by the 72 per cent sulphuric acid method. The form of lignin is soluble in sulphuric acid. The possible existence of a soluble form of lignin in the acid hydrolysates of woods has been recognized for many years but, until recently, few attempts have been made to isolate it. Von Wacek and Schroth $^{2,3}$ have emphasized the diffculties involved in such an isolation in view of the presence in wood hydrolysates of acids and sugars in addition to lignin. They show, however, that a substance of high methoxyl content (presumably lignin) can be extracted from spruce holocellulose by means of 24 per cent aqueous potassium hydroxide. This alkaline extract also contains hemicellulose. A somewhat elaborate procedure is outlined whereby the alkaline liquor remaining after removal of the hemicelluloses can be treated with acid and alcohol in such a way as to cause precipitation of the substance of high methoxyl content.

In work which has been contemporaneous with that of von Wacek and Schroth, a simple method has been evolved in this Laboratory for the isolation of soluble lignin from acid hydrolysates of wood and holocelluloses, and also from the mother liquors of hemicellulose preparations from beech wood. This method involves the use of ion exchange resins, and will be described in detail at a later date. At this stage the relationship between the lignin isolated by us, on one hand, and either that isolated by von Wacek and Schroth ${ }^{2}$ or the soluble lignin isolated by Stumpf and Freudenberg 4 from spruce and beech woods by means of cold, acidified dioxan and other solvents, on the other, is not known.

\section{R. C. McDonald}

W. G. CAMPBelL

Section of Chemistry,

Forest Products Research Laboratory, Princes Risborough, Aylesbury, Bucks.

Aug. 11.

${ }^{1}$ MeDonald, I. R. C., and Campbell, W. G., "Some Observations on the Delignification of Wood by Sodium Chlorite in Buffered Aqueous Solutions".

2 Von Wacek, A., and Schroth, D., Das Papier, 4, 410 (1950)

3 Von Wacek, A., and Schroth, D., Holz als Roh-und Werkstoff, 9, 7 (1951).

- Stumpf, W., and Freudenberg, K., Holz als Roh-und Werkstoff, 9, 199 (1951); from Angew. Chem., 64, 537 (1950).

\section{Constituents of Andrographis paniculata Nees}

IN the little work that has been done hitherto on the constituents of Andrographis paniculata Nees (Acanthaceæ) $)^{1}$ only Bhaduric has elaimed to have isolated a second bitter constituent in addition to the amaroid andrographolide. From the way in which he isolated and purified both products, it may be concluded that he obtained neither in a pure state.

On re-investigation of the herb, which is highly valued by the Indonesian people as a medicine for a great variety of diseases, besides the intense bitter 